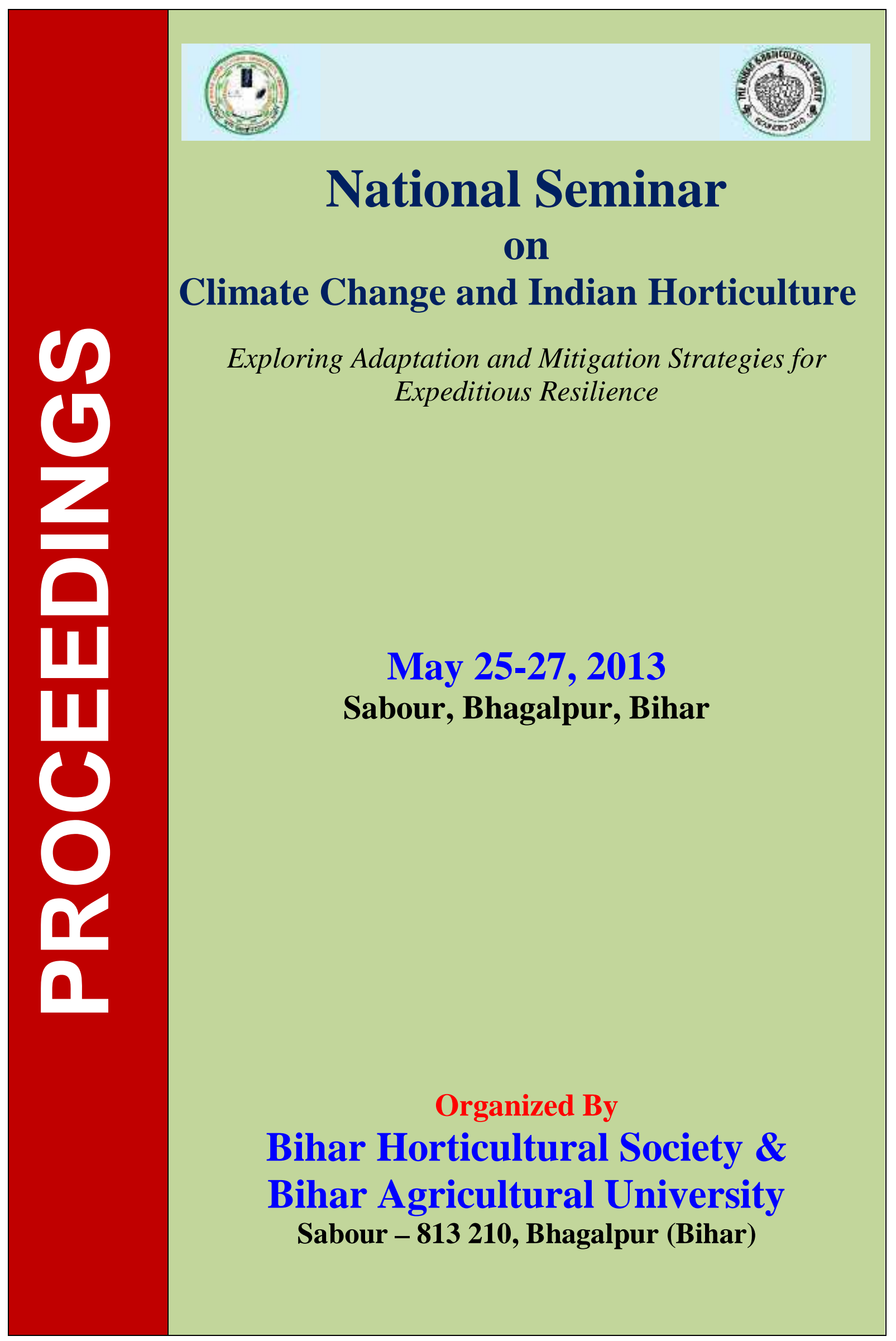




\section{(C) The Bihar Horticultural Society}

\section{Editorial Team}

Dr. V.B. Patel

Dr. Md. Wasim Siddiqui

Dr. S. Sheraz Mahdi

Declaration : Opinions in this publication are those of the respective authors and not necessarily that of the organisers.

\section{May, 2013}

\section{Published by}

\section{Dr. V.B. Patel}

Organizing Secretary, CCIH \& Chairman (Horticulture)

Department of Horticulture (Fruit and Fruit Technology)

Bihar Agricultural University

Sabour - 813 210, Bhagalpur, Bihar, India

Phone: 0641-2452613, 2451011 (O)

Fax: 0641-2452604

E-mail: patelvb7@gmail.com

Website: www.biharhorticulture.com

In Collaboration with

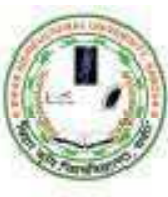

BAU

Sabour

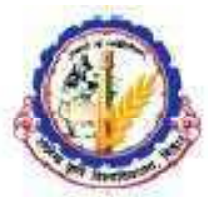

RAU

Pusa

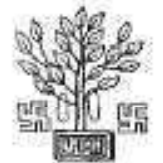

Ministery of Environment and Forests; Govt. of Bihar

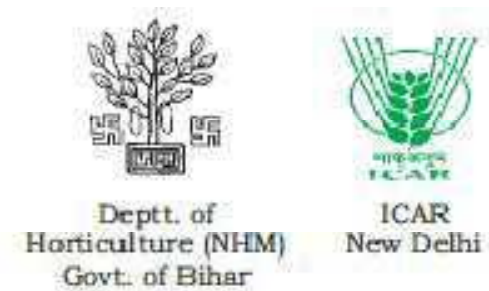




\title{
Empirical Appraisal of Some Weather Parameters Dynamics for Their Possible Implications on Mango Production in Some Important Mango Growing Regions with Special Reference to Lucknow Region of Uttar Pradesh
}

\author{
${ }^{1}$ Ravishankar, H., Tarun Adak, Singh, V.K., Pandey, B.K., Singh, A.K. and ${ }^{2}$ B.R. \\ Salvi \\ ${ }^{1}$ Central Institute for Subtropical Horticulture (ICAR), Rehmankhera, P.O. Kakori, \\ Lucknow-226 101, Uttar Pradesh \\ ${ }^{2}$ RFRS, Vengurle, Maharashtra \\ Email:drhravishankar@gmail.com
}

\begin{abstract}
The Intergovernmental Panel on Climate Change (IPCC) has projected a temperature rise of $1-3^{0} \mathrm{C}$ which may impact agriculture adversely, may reduce crop yields up to 10 per cent by 2020 for Asia (IPCC, 2007). Some Indian studies have indicated that 5-7 per cent decline in wheat yields for every degree Celsius increase in temperature given that current level of irrigation does not erode (Agarwal, 2009 ; Abdul Vahab Abdul Haris, 2013). Impacts and magnitude of climate change, a global phenomenon though not precisely understood as they become discernible at their tipping points, gradually increased risks originating from erratic weather, altering dynamics of pests and diseases have the potential to adversely impact crop yields and crop distribution in the country. Crop production dynamics in mango in different parts of the country in recent years is gripped with uncertainties due to occurrence of weather extremes, inadequacies of water and nutrient management and impacts of altered pests and diseases prevalence. The Konkan region of Maharashtra where the production of country's premier variety, 'Alphonso' is under monoculture getting impacted by weather vagaries for the last four years under the influence of western disturbances needs elaborate studies for understanding in order to develop adaptation and mitigation strategies. Despite some regional studies undertaken to profile the effects of some weather parameters on response of mango crop in some agro-ecologies, a clear understanding of its vulnerability to different phenophases events vis a vis production constraints is yet to emerge. This is especially important as mango production in recent years is getting adversely impacted by such weather variables as both high as well as low temperatures, unseasonal rainfall, floods, sunshine hours, relative humidity, wind speed etc., These variables potentially affected the different phenophases viz., vegetative growth dynamics, fruit bud differentiation, flowering, pests and diseases dynamics, fruit set and development, maturity, harvests and eventually the markets. Limited information however, is available on the understanding the impacts of weather components either individually or conjunctively influencing individual phenophases and their contribution to over all crop
\end{abstract}


outputs in order to put in place effective horticultural interventions. The spatio-temporal relationships and relative effects of critical weather variables on phenophases and crop productivity when appraised on collective and regional basis will facilitate development of models that could form part of the Decision Support System (DSS) for empowering growers' communities. Long term adaptation and mitigation strategies however need to entail studies on carbon sequestration, development of climate resilient varieties, improved crop husbandry practices for risk management, productive use of water and nutrient resources and integrated management of pests and diseases. The present paper based on inputs received from Maharashtra, Karnataka, Gujarat, Odisha, Bihar, Uttar Pradesh unfolds effects of some key weather parameters of three fruiting seasons on critical phenophases on mango production in some important mango producing regions with special reference to Lucknow region of Uttar Pradesh.

\section{INTRODUCTION}

Mango (Mangifera indica L.), the 'King of fruits' in India with rich variety diversity is grown in different agro-ecological regions of the country. Andhra Pradesh, Karnataka and Tamil Nadu in the south, Goa, Maharashtra and Gujarat in the west, Odisha, West Bengal and Bihar in the east and Uttar Pradesh in the north are the principal mango producing regions of the country. Among all the mango producing states, Uttar Pradesh contributes $23.85 \%$ of the total mango production out of $11.6 \%$ area under mango in the country. The recent CII-McKinsey report (2013) has identified mango, banana, potato, soybean, and poultry as five items to drive the next wave of growth in Indian agriculture.

Uttar Pradesh falling under the 'Indo-Gangetic plains' is categorized into nine agroclimatic zones. Eighty per cent of the state's population is agrarian of which about 91 per cent is represented by small farmers solely dependent on agriculture for their livelihoods. In the recent years, this sector is getting impacted by monsoon uncertainty, increasing duration of drought, floods in some areas and cold, and violent storms. Decrease in water table is progressing at an alarming rate and volume of water flow in major rivers is shrinking besides high levels of pollutants being discharged into the aquatic systems in their path. Soil sodicity is also a serious problem of the Indo-Gangetic plains in UP affecting the productivity and livelihoods of the people. It is estimated that approximately 1.3 million ha is affected by this problem accounting to more than 40 per cent of the cultivated area. Further, secondary salinization is also assuming serious proportions. Majority of these soils are having $\mathrm{pH}>10$, exchangeable sodium percentage (ESP) $>15$ and varying electrical conductivity (EC). These soils could be ameliorated by providing a readily available source of calcium $\left(\mathrm{Ca}^{2+}\right)$, to replace excess $\mathrm{Na}^{+}$on the cation exchange complex. The research for the past 30 years in sodicity has revealed some important reclamation methodologies for the top $0-15 \mathrm{~cm}$ of soil with gypsum and subsequent cultivation of paddy and wheat for providing food security to the farmers of sodic soils. Mango production in such problem soils though is ruled out, perhaps with 
introduction of salt tolerant rootstock (s) viz., $M$. indica L. cv.M-13-1 and $M$. zeylanica Hooker f., having features of higher rates of $\mathrm{CO}_{2}$ assimilation, root respiration, relatively low $\mathrm{Na}^{+}$and $\mathrm{Cl}$ contents along with higher $\mathrm{K}^{+}, \mathrm{Ca}^{++}$as well as $\mathrm{Mg}^{++}$in the leaves , besides exploring new rootstocks tolerant to abiotic stresses and standardizing them for commercial cultivars could open up new vistas of horizontal expansion of area under mango in the region.

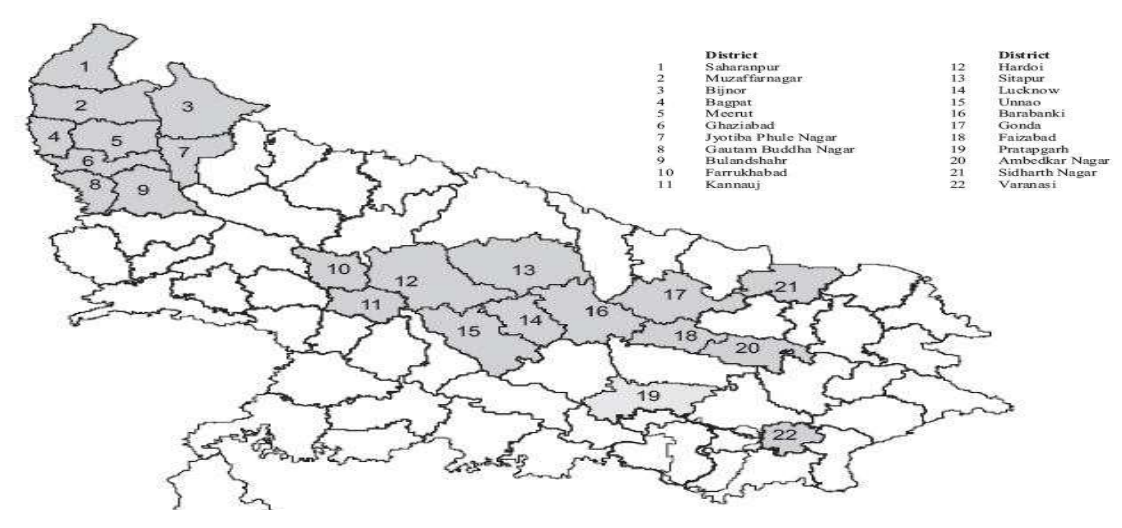

Figure 1. Mango map of Uttar Pradesh

Based on agro-climate suitability, the following regions /districts in Uttar Pradesh have been identified for promoting mango cultivation:

\begin{tabular}{|c|c|c|c|}
\hline & Crop & Variety dynamics & Major Clusters / Districts \\
\hline 1 & Mango & $\begin{array}{lr}\text { Dashehari, } & \text { Langra, } \\
\text { Chausa, } & \text { Amrapali, } \\
\text { Ramkela, } & \text { Lucknow } \\
\text { Safeda, Bombay Green }\end{array}$ & $\begin{array}{l}\text { Saharanpur, Meerut, Bulandshahar, } \\
\text { Bijnour, Moradabad, Muzaffarnagar, } \\
\text { Sitapur, Hardoi, Lucknow, Unnao, } \\
\text { Barabanki, Faizabad, Varanasi }\end{array}$ \\
\hline
\end{tabular}

Uttar Pradesh ranks third in fruit production among different states of the country with an area of 3.248 lakhs ha and production of 53.68 lakhs MT. There has been $7 \%$ and $15.2 \%$ increase in area under fruits in the state when compared with 1991-92 and 200506, respectively. Similarly, there has been $119 \%$ increase in fruit production when compared with 1991-92 and 71.1\% when compared with 2005-06. Uttar Pradesh accounts for $23.9 \%$ of mango produced by the country and represent the major livelihood crop in both eastern and the western parts of the state. Eastern U.P. where small and big rivers exist, is a chronically flood prone area, it has now been witnessing flash floods and instances of water logging in mango orchards have become frequent which can affect soil properties and nutrient dynamics besides pests and diseases dynamics. 
Prolonged drought, floods and hailstorms and decline in annual rainfall has become a regular feature over the last 3-4 years in the state. In some regions of U.P. drought has become recurrent. This is manifested by, low and untimely rainfall, increased temperatures leading to enhanced rate of vaporization, depletion of soil moisture arising due to reduced carrying capacity of water in the soil. Duration of cold has also increased as it happened in 2012-13 season, though its impact is yet to become discernible is also a case of uncertain weather dynamics. The mango belt of U.P. has been undergoing all these weather uncertainties the long term effects of which needs delineation (Ravishankar et al., 2011). The short term effects viz., disturbances to the phenophases, pests and diseases dynamics, delayed flowering (2013 fruiting season). Henceforth, analysis of extremism of weather components at farm scale is of great importance and the need for weather based agroadvisory forecasting system to sensitize the orchardists for adoption of appropriate strategies to avoid biotic and abiotic stresses in fruit production is increasingly felt (Adak et al., 2012).

\section{WEATHER VARIABLES AND GROWTH CORRELATIONS}

\subsection{Temperature}

\subsubsection{Vegetative growth}

The optimum temperature for tree growth has been reported to be $24-30^{\circ} \mathrm{C}$ (Bruce Schaffer et al., 1994); though it can tolerate air temperatures up to $48^{\circ} \mathrm{C}$, cold temperatures influence crop production. Sub-zero temperatures for even a single day or few hours severely damage or even kill the trees the trees as could be seen during the 2013 fruiting season in Lucknow (portion of twig death) and Dehradun region of Uttarakhand where nearly 10,000 trees have been reportedly dead. Trees manifest strong vegetative bias with increasing temperatures provided; water and nutrients are not limiting (Whiley et al., 1989). They observed that the median (mean of the maximum and minimum daily temperatures) daily temperature for zero shoot growth of ten mango cultivars to be $15^{\circ} \mathrm{C}$ which, was subsequently confirmed to be critical for critical daily mean temperature for vegetative growth. Soil temperatures reportedly have a strong control on synchronization of growth phases in the tree. The same authors found that periodic shoot growth, changing between phase of activity and dormancy, occurred when soil temperatures were held at $27^{\circ} \mathrm{C}$ or $32^{\circ} \mathrm{C}$ for 120 days but at $21^{\circ} \mathrm{C}$ an extended dormant period developed. Temperature also influenced the number and size of leaves. An average of 7.1 leaves that developed on shoots at $20 / 15^{\circ} \mathrm{C}$ increased to 13.6 at $30 /$ $25^{\circ} \mathrm{C}$. Dry matter partitioning to roots was the greatest in trees growing at $15 / 10^{\circ} \mathrm{C}$ i.e., temperatures that suppressed shoot growth. With increase in temperatures, partioning to roots declined but correspondingly increased for stem and leaves. In 'Irwin', there was a greater allocation of dry matter to roots at higher temperatures of $25 / 20^{\circ} \mathrm{C}$ and $30 /$ $25^{\circ} \mathrm{C}$, a reflection of its reduced flushing and semi-dwarf architecture.

\subsubsection{Reproductive growth}


Studies under controlled conditions have shown, of the different weather variables, temperature exerts an important influence on different components of reproductive phenology starting right from flowering (Bruce Schaffer et al., 1994). They opined that mango gets affected when temperature falls below $0^{0} \mathrm{C}$, hence low temperature factor more than others defines the range of its cultivation. A period of stress generally precedes flowering, which occurs following stress relief, and temperature, particularly in the subtropics provides the strong environmental stimulus for flower induction, the threshold being cultivar-specific. On the contrary, dry period preceding flowering appears necessary for satisfactory flowering in the tropics highlighting the role of drought stress to be the key environmental cue. Studies of Pongsomboon (1991) showed that no flowering occurred in trees held at $30 / 20^{\circ} \mathrm{C}$ at either soil temperatures, while at $15 / 10^{\circ} \mathrm{C}$ air or $12.5^{\circ} \mathrm{C}$ soil temperature, all the trees had flowered after 16 weeks but only 40 per cent trees flowered when soil temperatures were held at $25^{\circ} \mathrm{C}$. These results suggested that 'root signals' probably played significant role in induction of flowering in mango. Similar indications from the work of Ravishankar (1987) on Alphonso (alternate bearer) and Totapuri (regular bearer) strengthens this view. Export of cytokinins from roots impacting reproductive morphogenetic responses of shoots under the influence of temperature cannot be ruled out as high temperatures provided increased vegetative bias in mango (Whiley et al., 1989). The fact that foliar gibberellins applications suppressed flowering in mango despite trees being grown in inductive conditions (Kachru et al., 1971) emphasizes that interpolations of promoters and inhibitors under the influence of high soil temperatures perhaps play crucial role in coordinating shoot-root communication (Ravishankar,1987) ultimately determining the flowering responses in mango which however needs further investigation as major focus of research so far in mango focused on signals and responses generated in shoots (Ravishankar,1987 and Chacko, 1991).

Issarakraisila et al., (1992), reported that mean temperature of $12-15^{\circ} \mathrm{C}$ sustained panicle growth in mangoes of the subtropics. Singh et al., (1965) found temperature dependency of male and hermaphrodite flowers dynamics of the panicles. Their study indicated that late emerging panicles of 'Dashehari' had seven times the percentage of perfect flowers as compared to early emerging panicles on the same trees with mean maximum / minimum temperatures of $20.7^{\circ} \mathrm{C} / 3.7^{\circ} \mathrm{C}$ and $27.3^{\circ} \mathrm{C} / 13.1^{\circ} \mathrm{C}$ for early and late emerging panicles respectively signifying higher temperatures during panicle development are conducive. They also found much less percentage of hermaphrodite flowers in some south Indian cultivars when grown in northern India which was attributed to prevalence of lower maximum / minimum temperatures during panicle development as compared to south Indian conditions during the corresponding periods of panicle development .

Studies have shown, $\mathrm{T}_{\min }\left(<15^{\circ} \mathrm{C}\right)$ during the development of inflorescences resulted in deformation of flowers which were smaller as compared to those that developed at about $7^{0} \mathrm{C}$ higher (Issarakraisila et al., 1992) and these abnormal flowers at such low 
temperatures had small ovary, dark and reduced style length, dark ovule and black anther instead of the red one; pistil abnormalities ensued. Issarakraisila and Considine (1994) noted, although mature pollen was tolerant to low temperatures even at $10^{\circ} \mathrm{C}$, this temperature being critical during meiosis, below which the pollen viability falls to about 50 per cent. They further observed, prevalence of high temperatures of $36^{\circ} \mathrm{C}$ and above during the pre-vacuolate -meiosis stage of microsporogenesis of pollen drastically reduced the pollen viability.

Besides the above, unseasonal rains especially at the time of fruit bud differentiation (FBD) could transform the already differentiated shoot meristems in favor of reproductive ones to vegetative ones, attributable to their unfavorable intervention in the requirements of drought stress in the tropics while, low temperature in the subtropics ; occurrence of frost $\left(-0.2^{0} \mathrm{C}\right.$ to $-1.2^{0} \mathrm{C}$ on $9^{\text {th }}$ and $10^{\text {th }}$ January, 2013) as it happened at CISH, Lucknow however virtually killed a portion of the shoots and triggered the emergence of new vegetative flushes from the lateral buds subtending the dead portion of shoots, thus contributing to transgression of tree physiology from an expected reproductive one predominantly. Perhaps this was also compounded by the occurrence of hailstorm on $18^{\text {th }}$ and $19^{\text {th }}$ January 2013. Such a situation altered the dynamics of trips incidence in several cases, resurgence on new vegetative flushes despite spraying of thiomethoxam $(0.02 \%)$ and in some instances, damages to the fruits at pea stage of development. Temperature dynamics together with soil moisture conditions (due to unseasonal rainfall that occurred on 18 and $19^{\text {th }}$ January, 2013) that prevailed during 2013 witnessed however, below threshold levels incidence of mealy bugs, hoppers and powdery mildew. Summary responses of different phenophases to weather variables across standard meteorological weeks and their implications in inciting production constraints of 'Dashehari' during 2010-12 are indicated in Table 2.

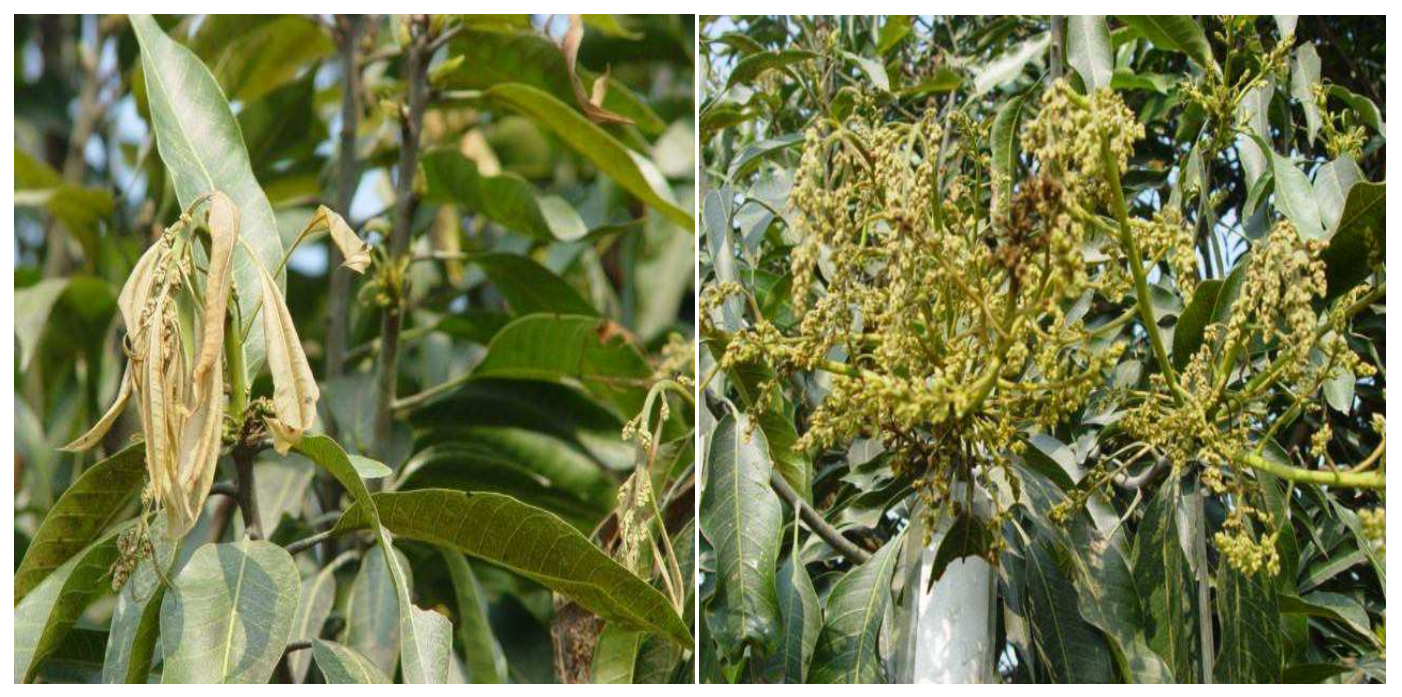

Photograph.1.Inflorescence deformities due to low temperature effects 
$\left[\mathrm{T}_{\min }<15^{\circ} \mathrm{C}\right]$ during 2013 fruiting season at CISH, Lucknow

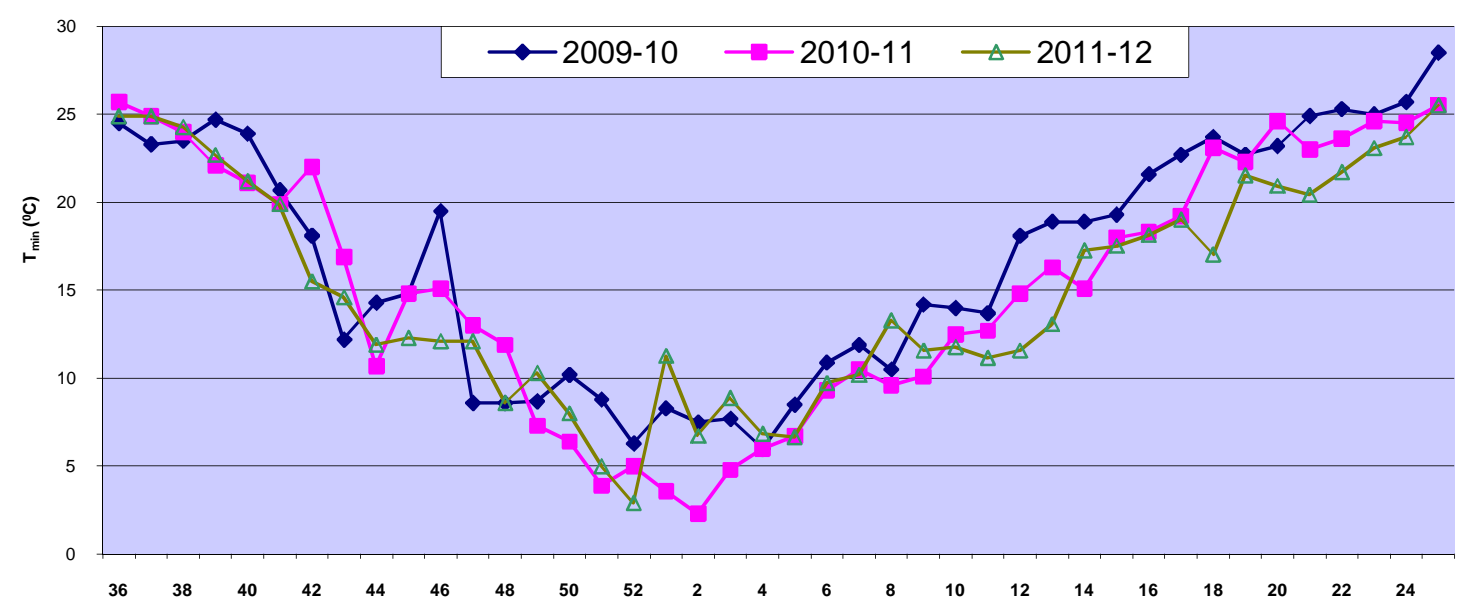

Figure 2 . Weekly mean maximum temperature fluxes of the study period

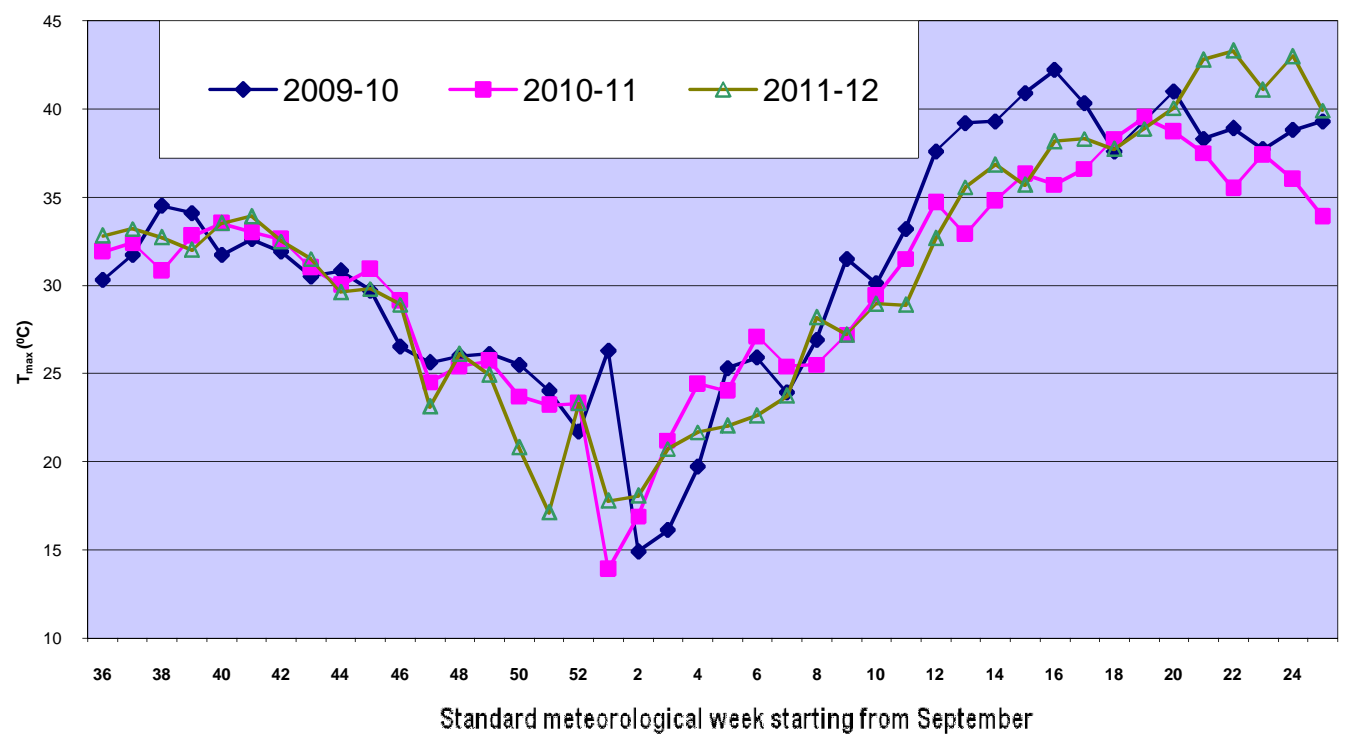


Figure 3. Weekly mean minimum temperature fluxes of the study period

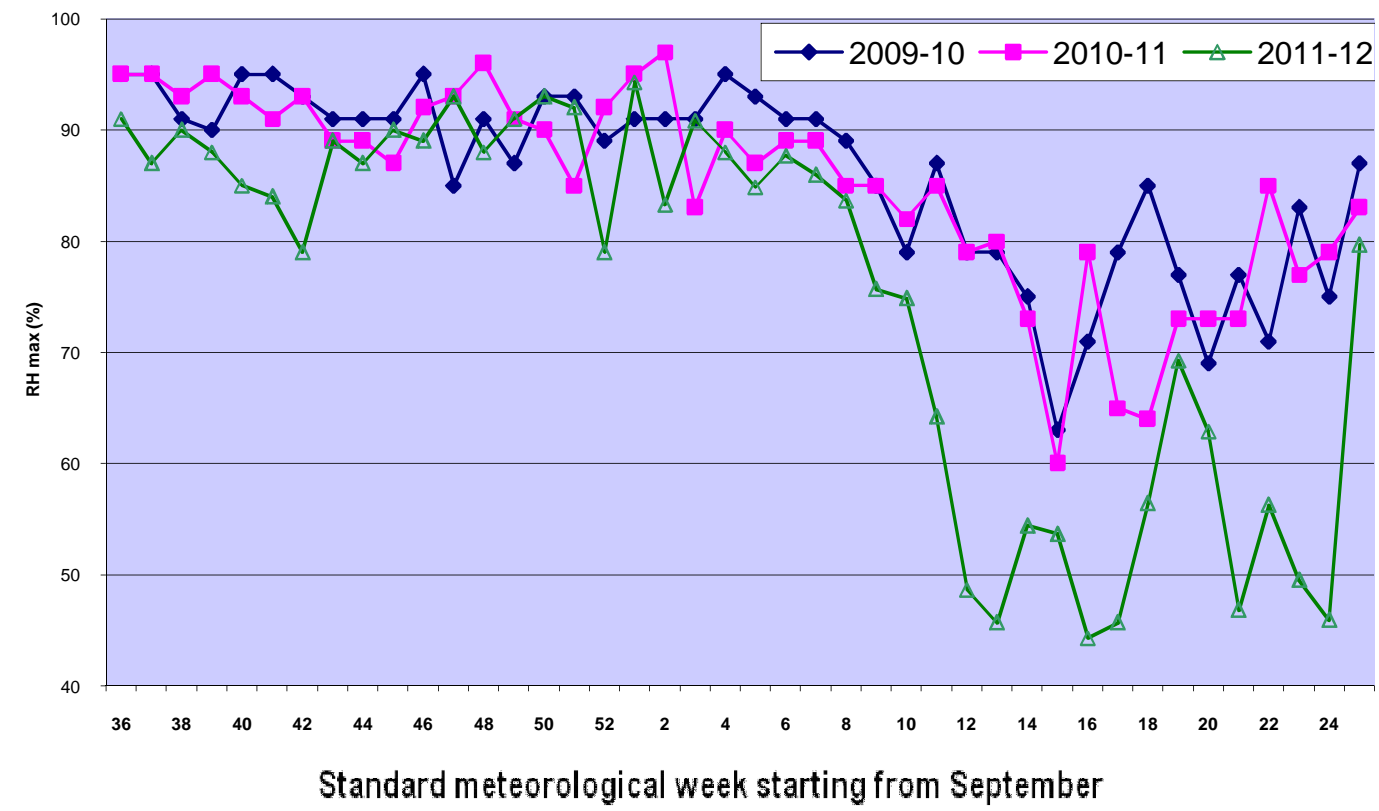

Figure 4. Weekly mean maximum relative humidity fluxes of the study period

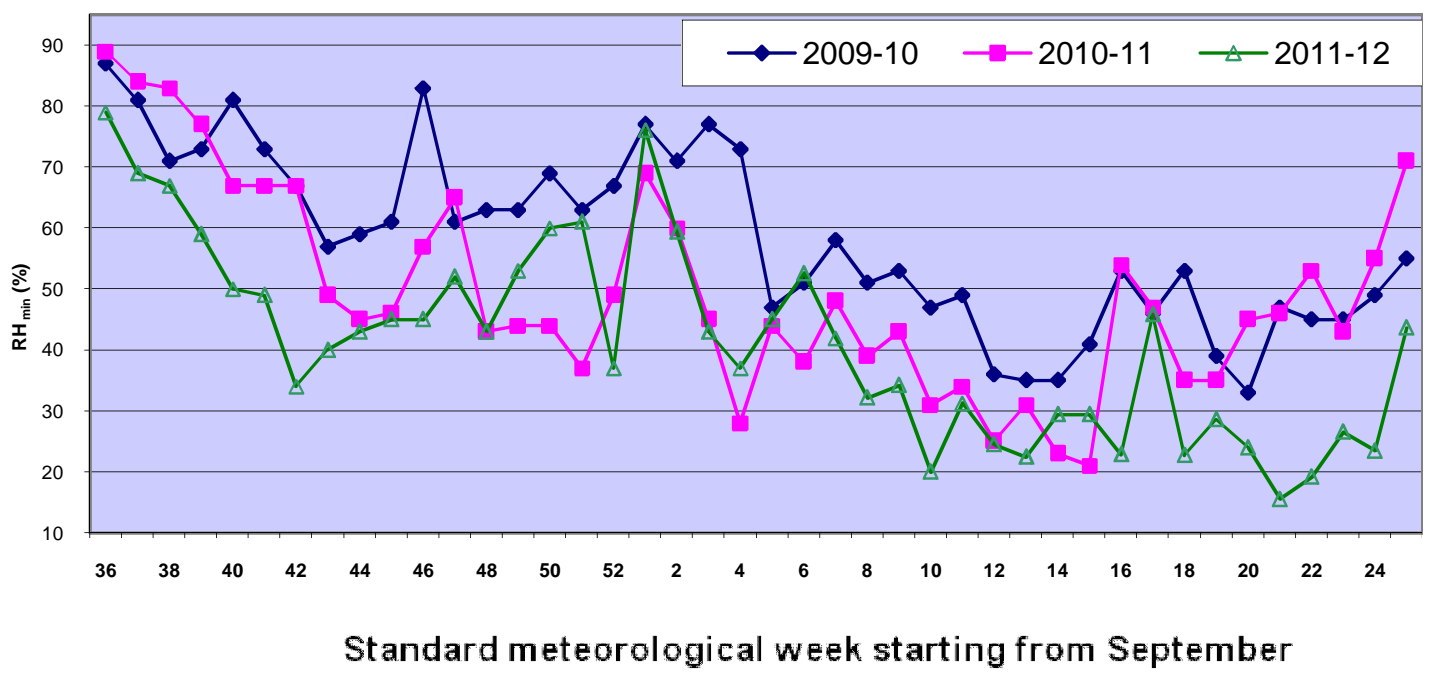

Figure 5. Weekly mean minimum relative humidity fluxes of the study period 


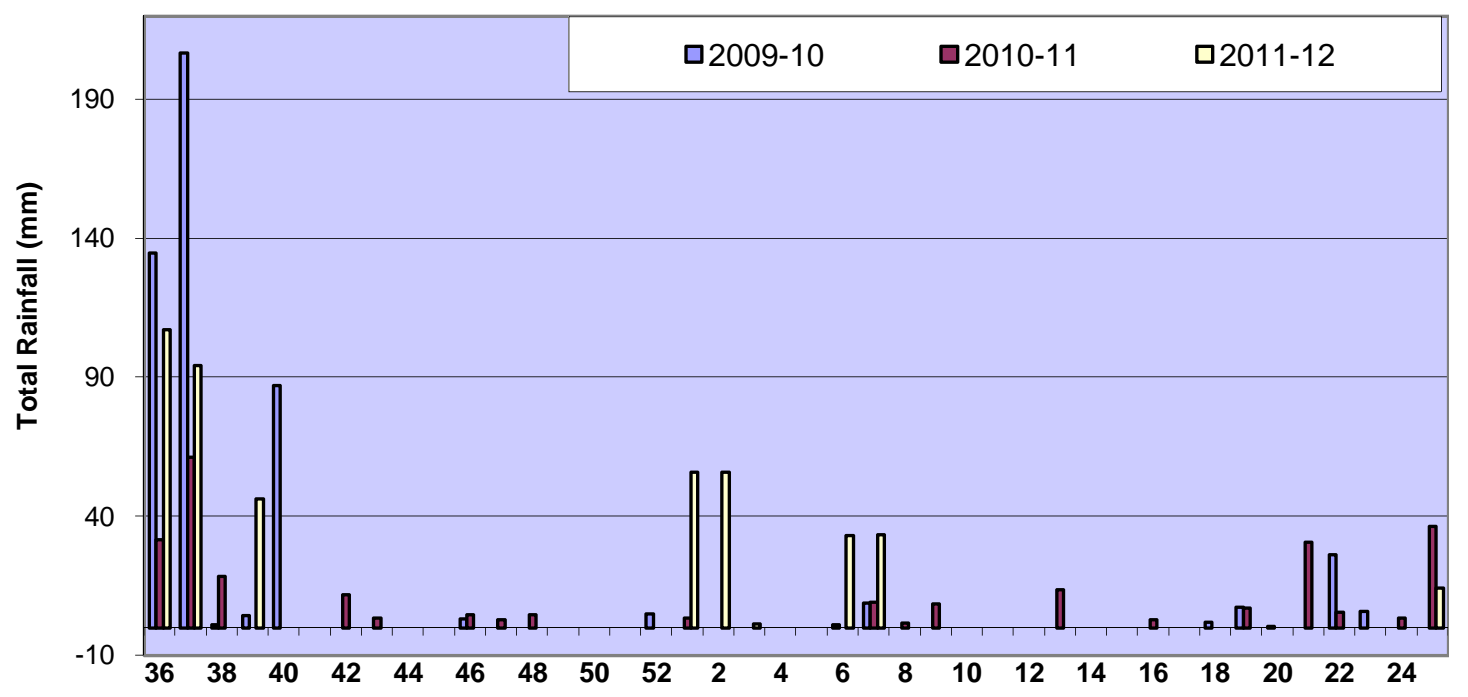

Standard meteorological week starting from September

Figure 6. Weekly mean rainfall during the study period 

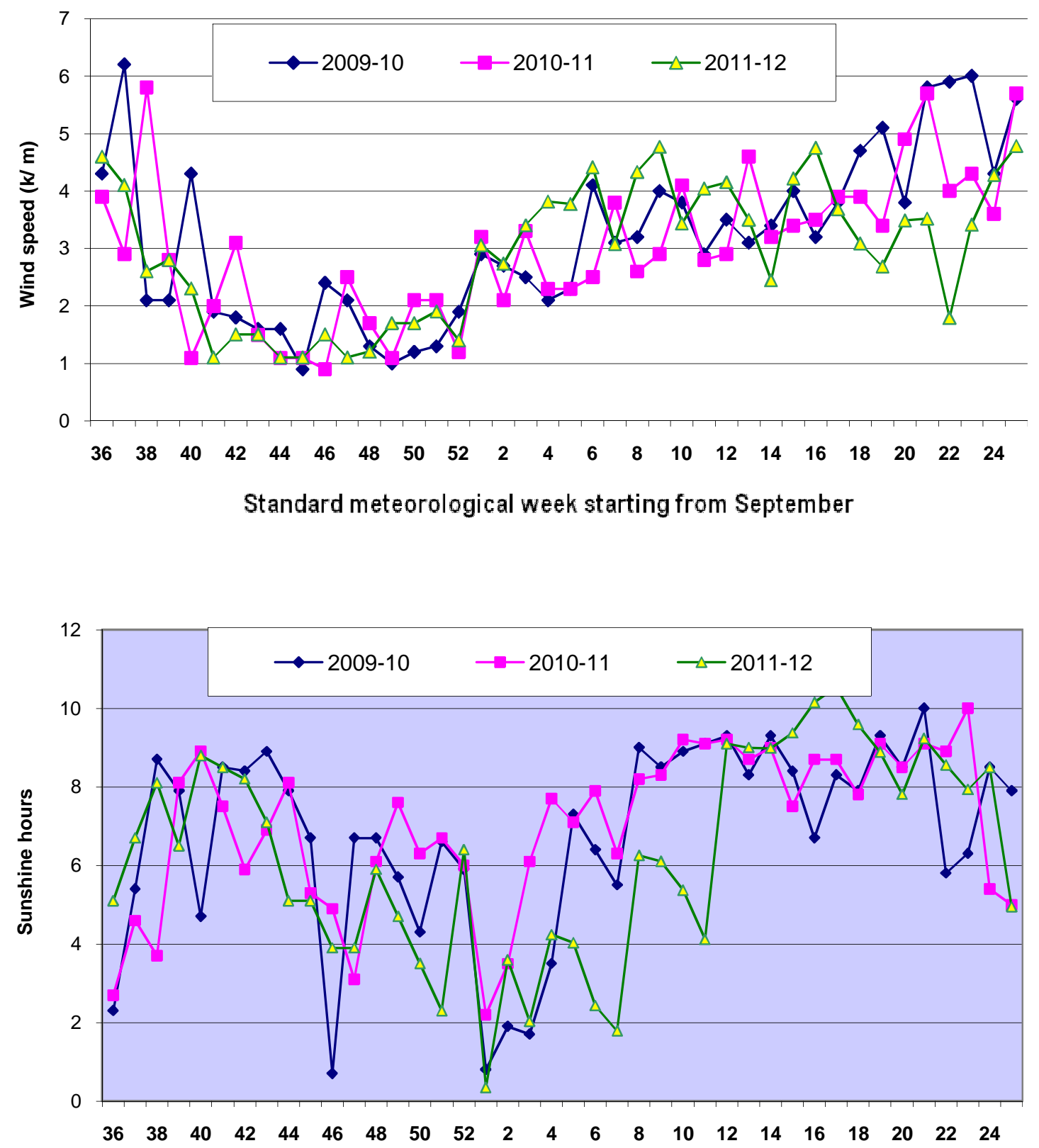

Standard meteorological week starting from September

Figure 7. Weekly mean wind speed (above) and sunshine hours (below) of the study period 


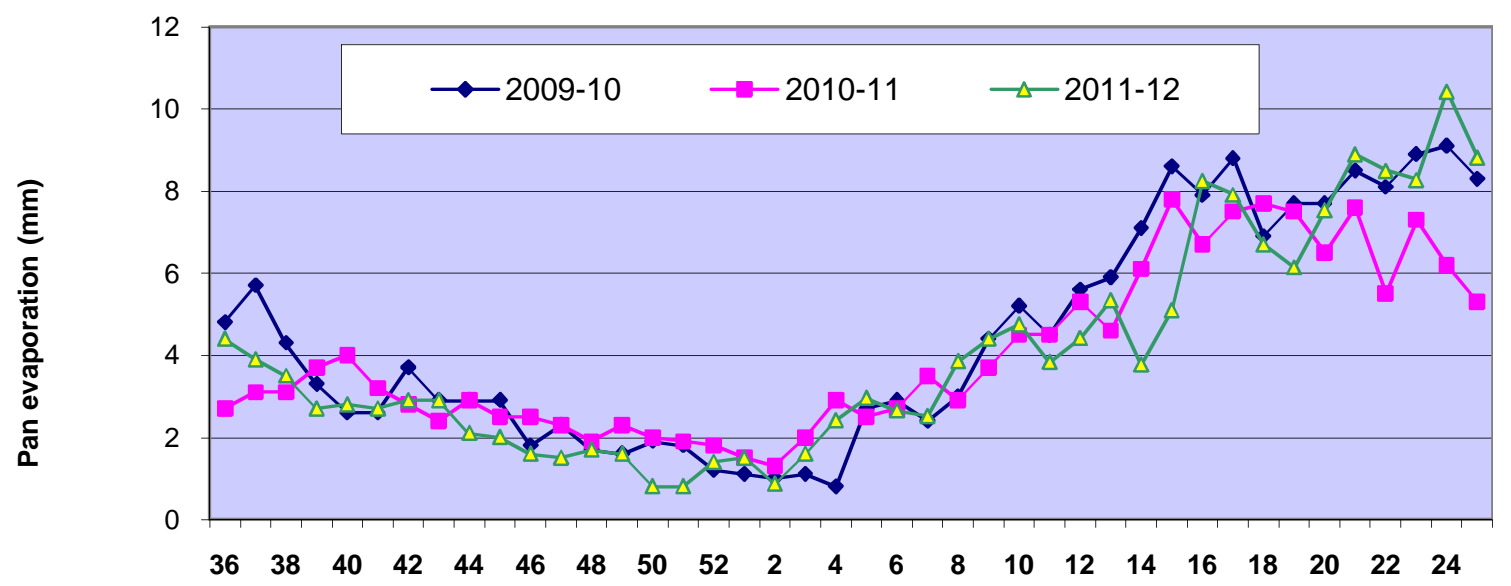

Standard meteorological week starting from September

Figure 8. Weekly mean values of pan evaporation during the study period

\subsubsection{Physiological attributes}

Under subtropical conditions, flowering in mango is influenced by cool temperatures, although the temperatures reported for cold induction in mango are much higher than those reported for vernalization. Vegetative growth in mango is through episodic flushing, which was more frequent as per temperature increases recorded during 2013 fruiting season in the Lucknow region.

Mango being a $\mathrm{C}_{3}$ plant, the photosynthetic performance among cultivars is important for productivity under variable climatic conditions. Higher photosynthetic efficiency during reproductive phenophases especially flowering and fruit growth was identified as the important traits contributing to higher productivity. Under Lucknow conditions photosynthetic fluxes under different temperature regimes in 25 cultivars representing different agro-climatic regions of the country was evaluated (Singh and Rajan, 2009) where in the commercial cultivars of Lucknow region were found more efficient as compared to others. Precise understanding of effects of light interception patterns in mango canopies on productivity is seriously constrained by lack of sufficient quantitative data.

A key enzyme associated with abiotic stress responses of crops, Rubisco limited rate of photosynthesis is less sensitive to temperature as the decrease in carboxylation at low temperatures is partially compensated by suppression of photorespiration. RUBPregeneration limited rate of photosynthesis which depends upon much less on oxygenation however, is fairly sensitive to temperature. Observations at CISH, Lucknow on different varieties of regular (Amrapali, Totapuri) and biennial (Langra, Chausa, 
Dashehari) during different phenophases which experienced range of temperatures in 2012-13, exhibited different levels of sensitivity to low temperatures for their photochemical reaction (Personal observation and Singh et al., 2012).

Table 1: Competence of important phenophases in respect of key vulnerable physiological attributes in 'Dashehari' to weather dynamics

\begin{tabular}{|l|l|l|}
\hline Type of shoot/stage & $\begin{array}{l}\text { Rate of } \\
\text { photosynthesis }(\mathbf{P N}) \\
\left(\boldsymbol{\mu} \mathbf{~ m o l ~ m}^{-2} \mathbf{s}^{-1}\right)\end{array}$ & $\begin{array}{l}\left.\text { Leaf water potential } \mathbf{( \Psi}_{\mathbf{w}}\right) \\
(\mathbf{M P a})\end{array}$ \\
\hline Vegetative growth & 9.25 & -7.36 \\
\hline Reproductive growth & - & - \\
\hline a) FBD & 7.61 & -7.95 \\
\hline b) Flowering & 6.25 & -8.46 \\
\hline c) Fruit set & 7.27 & -6.50 \\
\hline
\end{tabular}

Higher amounts of PN with concomitantly high leaf water potential during periods of rank vegetative growth (March and September-November) coincided with periods characterized by the prevalence of high temperatures and soil moisture and hence they are found vulnerable .FBD, a metabolically highly dynamic stage also maintained high PN levels obviously indicating high sink activities with correspondingly high leaf water potential, however a period of stress precludes this phenomenon and under subtropical conditions, this is provided by cold . This stage could turn out to be vulnerable, if intervened by heavy rainfall so that the reproductive primordia could revert to the vegetative one. Such an unfavorable event did not occur during the study period (Figures. 2-8 . Standard meteorological weeks starting from September, 42-46) . Decrease in PN in leaves during flowering is attributable to the decrease in stomata conductance. Reduction in this parameter could also be due to differences in the leaf water state of shoots. Thus it is possible that flowering results due to local water stress. Increase in PN during fruit set could be attributed to higher sink activity demanding increased mobilization of photosynthates to the developing fruit lets. Based on the pattern of flushing, the maximum flushes were recorded during March in both the years. However, in 2011 the significantly higher flush was also recorded during June-August (16.91-38.26\%) in addition to March flushing which is attributed to relatively lower intensity of reproductive phase of the previous fruiting season . 


\begin{tabular}{|c|c|c|c|c|c|c|c|c|c|}
\hline \multirow{2}{*}{$\begin{array}{l}\text { Standard } \\
\text { meteorological } \\
\text { week } \\
\text { (provisional) }\end{array}$} & \multirow{2}{*}{$\begin{array}{l}\text { Calendar } \\
\text { month }\end{array}$} & \multicolumn{7}{|c|}{ *Vulnerable phenophases / production constraints } & \multirow{2}{*}{$\begin{array}{l}\text { Meteorological } \\
\text { culture event }\end{array}$} \\
\hline & & $\begin{array}{l}\text { Vegetative } \\
\text { flush }\end{array}$ & FBD & Flowering & $\begin{array}{l}\text { Fruit } \\
\text { set }\end{array}$ & Development & Maturity & Harvesting & \\
\hline \multirow[t]{2}{*}{$\begin{array}{l}42,43,44,45,46 \\
47\end{array}$} & \multirow[t]{2}{*}{$\begin{array}{l}\text { October - } \\
\text { November }\end{array}$} & $\begin{array}{l}* \\
\text { (Leaf webber ; } \\
\text { anthracnose) }\end{array}$ & $*$ & - & - & - & - & - & $\begin{array}{l}\text { High temperature ; } \\
\text { un-seasonal rainfall }\end{array}$ \\
\hline & & $\begin{array}{l}* \\
\text { (Leaf webber ; } \\
\text { anthracnose) }\end{array}$ & $*$ & - & - & - & - & - & $\begin{array}{l}\text { Un-seasonal rainfall; } \\
\text { low temperature }\end{array}$ \\
\hline \multirow[t]{2}{*}{$\begin{array}{l}48,49,50,51,52 \\
1,2,3,4\end{array}$} & \multirow{2}{*}{\begin{tabular}{|l|} 
Last week \\
of \\
November, \\
December - \\
January
\end{tabular}} & - & $*$ & $*$ & - & - & - & - & $\begin{array}{l}\text { Low temperatures and } \\
\text { its duration }\end{array}$ \\
\hline & & $*$ & - & $\begin{array}{l}* \\
\text { (Mealy bugs) }\end{array}$ & - & - & - & - & $\begin{array}{l}\text { Low temperatures and } \\
\text { frost }\end{array}$ \\
\hline $\begin{array}{l}5,6,7,8,9,10,11, \\
12\end{array}$ & $\begin{array}{l}\text { First week } \\
\text { of } \\
\text { February - } \\
\text { March }\end{array}$ & $\begin{array}{l}* \\
\text { (Thrips; } \\
\text { anthracnose) }\end{array}$ & - & $\begin{array}{l}* \\
\text { (Full bloom; } \\
\text { inflorescence } \\
\text { midge ; } \\
\text { hoppers }\end{array}$ & $\begin{array}{l}* \\
\text { (Nubbin } \\
\text { fruits ) }\end{array}$ & $*$ & - & - & $\begin{array}{l}\text { Low / High } \\
\text { temperatures } \\
\text { unseasonal rainfall/ } \\
\text { excessive irrigations ; } \\
\text { high relative humidity }\end{array}$ \\
\hline
\end{tabular}




\begin{tabular}{|c|c|c|c|c|c|c|c|c|c|}
\hline & & & & $\begin{array}{l}\text {;blossom } \\
\text { blight ; } \\
\text { powdery } \\
\text { mildew ; } \\
\text { extent; } \\
\text { intensity; } \\
\text { panicle } \\
\text { configuration- } \\
\text { per cent } \\
\text { hermaphrodite } \\
\text { flowers ; } \\
\text { pollinators' } \\
\text { activity) }\end{array}$ & & & & & \\
\hline $\begin{array}{l}13,14,15,16,17 \\
18,19,20,21\end{array}$ & $\begin{array}{l}\text { Last week } \\
\text { of March, } \\
\text { April-May }\end{array}$ & $\begin{array}{l}\text { * } \\
\text { (Thrips; } \\
\text { anthracnose ) }\end{array}$ & - & - & $\begin{array}{l}* \\
\text { (Pre- } \\
\text { harvest } \\
\text { fruit } \\
\text { drop ; } \\
\text { fruit } \\
\text { growth ; } \\
\text { fruit fly } \\
\text { ) }\end{array}$ & $\begin{array}{l}* \\
\text { (Pre-harvest } \\
\text { fruit drop ; } \\
\text { fruit growth; } \\
\text { fruit fly ; fruit } \\
\text { borer ; fruit } \\
\text { midge ) }\end{array}$ & $\begin{array}{l}* \\
\text { (Pre-harvest } \\
\text { fruit drop ; } \\
\text { size) }\end{array}$ & - & $\begin{array}{l}\text { Absence of rainfall / } \\
\text { impaired } \\
\text { management ; } \\
\text { temperatures }\end{array}$ \\
\hline $\begin{array}{l}22,23,24,25 \ldots . . \\
\text { up to } 35\end{array}$ & $\begin{array}{l}\text { June-July- } \\
\text { August }\end{array}$ & \{ Shoot gall & & - & - & - & - & (maturity ; & $\begin{array}{l}\text { High temperatures } \\
\text {,high rainfall , high }\end{array}$ \\
\hline
\end{tabular}




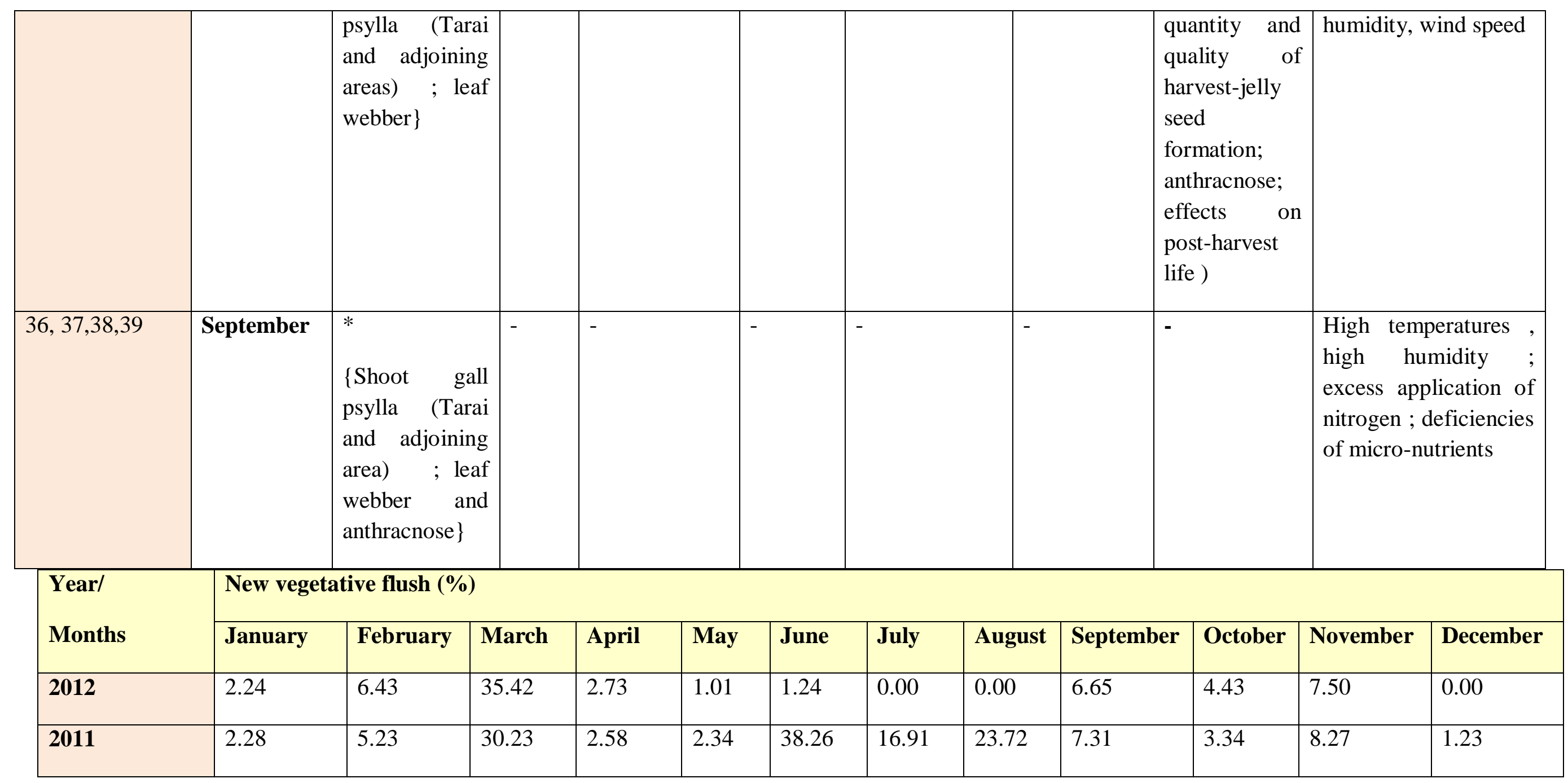




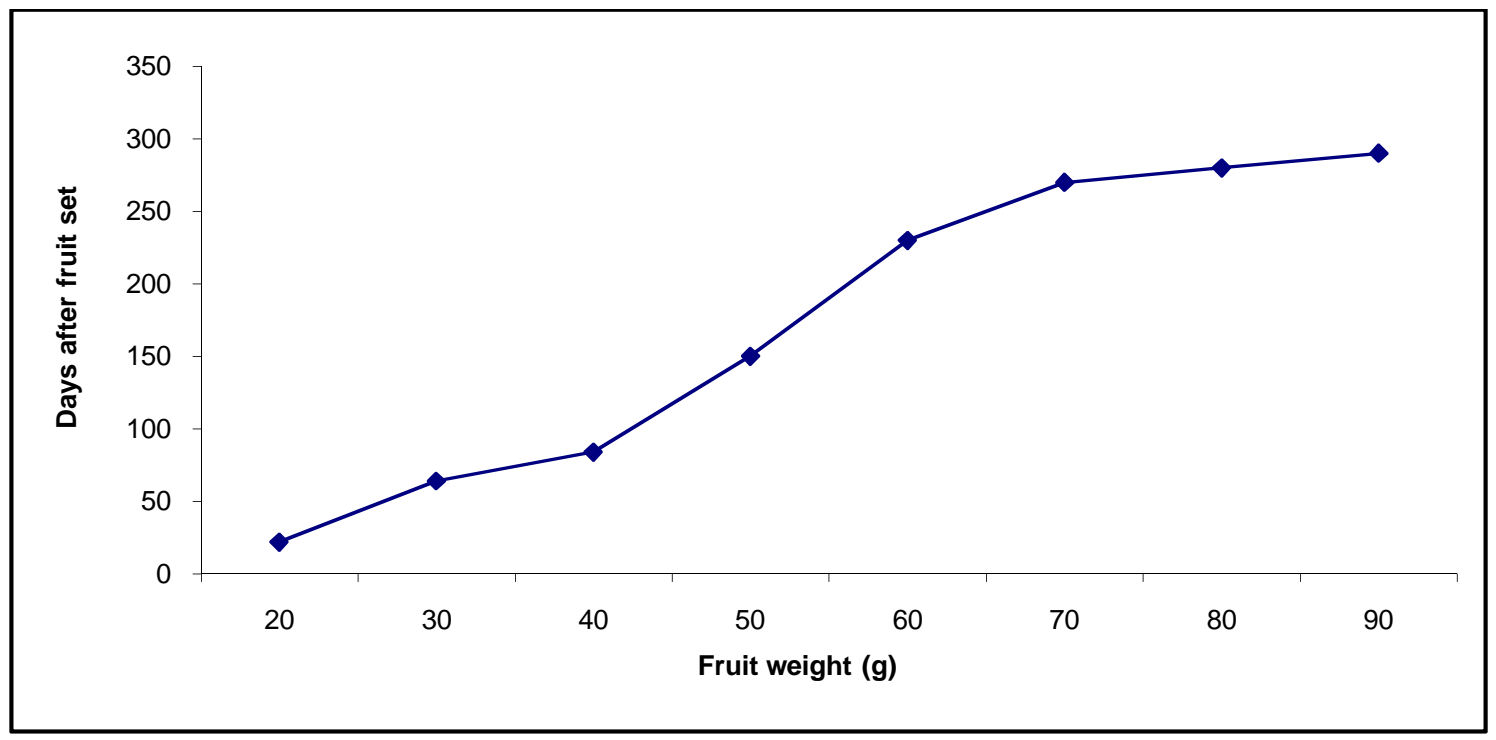

Figure 9. Stages of fruit growth and development in 'Dashehari' and their relative vulnerability to weather variables

[ Initiation (up to 20 days-30 days)- February- March ; vulnerable to temperature and moisture dynamics ; Lag phase -30-40 days - March-April- vulnerable to high temperatures; low RH ; moisture dynamics and under hormonal interpolations; fruit borer ; pre-harvest fruit drop ;Grand growth phase - 40-70 days - April-May vulnerable to hormonal interpolations; nutrients and water dynamics ; fruit fly ; preharvest fruit drop; shoulder browning if exposed to rainfall; consolidation of fruit quality principles Climacteric -70-80 days - Mid June- Mid July; high temperature effects on fruit size and quality ; harvest maturity ; jelly seed formation , exposure to rainfall ; Senescence- 80 days onwards- high temperature effects ; concentrated maturity ; market gluts ; exposure to rain fall ; reduced profitability ]

Fruits approaching maturity are greatly affected by high temperatures exceeding $35^{\circ} \mathrm{C}$ as it happened in the Konkan region (day temperatures peaking to $40^{\circ} \mathrm{C}$ and beyond in May) during 2010 fruiting season where crores worth 'Alphonso' mangoes was lost while in 2011 fruiting season in Malihabad area of Lucknow witnessed sharp focused maturity and market gluts during the third week of June when the day temperatures peaked to $43^{0} \mathrm{C}$, a sudden increase of $2^{0} \mathrm{C}$ over the previous week in a short span of a week's time.

\section{Spatio-temporal relationships between temperature dynamics and phenology at some important mango producing regions}

Meteorological observations at CISH, Rehmankhera indicated that fruit development stages were vulnerable under high pan evaporation regimes (>6 mm / day to $10 \mathrm{~mm} /$ day) particularly during the last week of March and onwards. High pan evaporation values indicated higher rate of evapo-transpiration resulting into drier soils with soil moisture stress developing silently within the soil and leading to abiotic stress complexes barring 
water and nutrient flow through xylem. Thus protective irrigations are required as an intervention strategy so as to maintain optimum soil moisture and leaf water potential in order to sustain fruit set, growth and development and minimizing pre-harvest fruit drop unless otherwise this period is intervened by unseasonal rains. Reports have indicated that mango is drought tolerant, due its ability to maintain turgor through osmotic adjustment attributable to the existence of lacticifer system. Mango , on the other hand, exhibit some degree of flood tolerance though production of hypertrophied lenticels that facilitate increased $\mathrm{O}_{2}$ absorption besides offering sites for excretion of toxic by-products of anaerobic metabolism of roots (Bruce Schaffer et al., 1994). Perhaps flooding tolerance of mango trees in north Bihar could be explained to the above mentioned phenomenon. Precise understanding of these features however, is constrained by the lack of quantitative data on water relations.

The vulnerability of mango to weather dynamics also emerged at some other important mango growing parts of the country. A recurrent flowering phenomenon, which has become common in the Konkan and Bangalore regions for the past four years appears to be a consequence of weather impacts which needs micro-analysis with at least the Konkan case coming under the influence of western disturbances occurring over the Arabian sea. Meteorological data analysis at Bangalore indicated that $\mathrm{T}_{\min }$ ranged between 13 to $16^{\circ} \mathrm{C}$, on majority of the days during January 2013 being $14-15^{\circ} \mathrm{C}$, a critical period for flowering. In the first fortnight of January 2013, $\mathrm{T}_{\min }$ ranged between $10-16^{\circ} \mathrm{C}$. Hence during January 2013, attributable to this variation, flowering occurred in more than one flush, termed 'recurrent flowering'. This kind of phenomenon was also reported in 'Kesar' from Gujarat (Personal communication, 2013) which has led to occurrence of different stages of fruit growth and development stages on the same tree, consequently multiple harvests of varying quality may ensue affecting markets. During February 2013 , the $\mathrm{T}_{\max }$ was $28.7^{\circ} \mathrm{C}$ and the $\mathrm{T}_{\min }$ was $17.4^{\circ} \mathrm{C}$ with the $\mathrm{RH}$ of $73 \%$. The data recorded for two fortnights revealed that there was only very little difference in $\mathrm{T}_{\max }$ and $\mathrm{T}_{\text {min. }}$. However, large variations in the $\mathrm{T}_{\min }$ emerged during February 2013. On some days, the $\mathrm{T}_{\min }$ was $21^{\circ} \mathrm{C}$ and after a gap of 6 to 7 days, the $\mathrm{T}_{\min }$ fell to $14^{\circ} \mathrm{C}$. Such variations in $\mathrm{T}_{\min }$ could greatly affect the pollinator dynamics and their activity as was discernible during 2013 fruiting season at Lucknow and adjoining regions. This kind of $\mathrm{T}_{\min }$ dynamics also probably triggered a second flush of flowering during 2013 at Bangalore region, infusing disturbed source-sink relationships as fruits of different growth and developmental stages became mutually competitive that could probably impact both quantity as well as quality of harvests . February 2013, however, witnessed $\mathrm{T}_{\text {min }}$ fluctuating between 13 to $15^{\circ} \mathrm{C}$ without much change.

Under the Konkan conditions of Maharashtra, new vegetative flushes emerged in the second week of November (2011-2012). The first flowering flush to the tune of about $5 \%$ occurred in the third week of December even though there were extended rains up to $29^{\text {th }}$ November, 2011 in continuation to normal rainfall in the monsoon. The second flowering flush was noticed during January second week which was to the tune of about 30\%. The total flowering up to March, 2012 in 'Alphonso' was about $48 \%$ and in other 
varieties it was about $25 \%$. The late showers received up to November end affected the fruit set of the first flowering flush as the flowering got delayed despite hermaphrodite flower percentage in the first flowering flush being normal up to $9.8 \%$; the panicles emerging during second flowering flush were predominantly of mixed panicles having extra length (size-41 cm length) that contributed to low fruit set as was seen at Vengurle, Mulde, Deogad and Lanja in about $10.4 \%$ plants in both cases there was failure to set any fruits .

Since 2009, unpredictable weather conditions have been occurring in the premier mango growing belts of the country every year, like incidence of unseasonal rains (up to Dec. 23; March-May); cloudy weather, severe cold (8 to $12^{\circ} \mathrm{c}$ ), and extremes of $\mathrm{T}_{\text {min }}$ continuously for 60 to 70 days, (instead of 4 to 5 spells of 12 to 15 days cold period) and $\mathrm{T}_{\max }$ prevailing during fruit growth, development and maturity. These aspects have come to sharp focus from 2009 onwards especially the Konkan region. The normal rainfall period of this region is June to September with 1 to 2 dry spells of 8 to 10 days period, with mean annual rainfall of $3000 \mathrm{~mm}$ received over an average of 105 days. However, deviations to this normal showed, the extended rainfall (15 to 42 days) with increased intensity $(122 \mathrm{~mm}$ to $1500 \mathrm{~mm})$. This situation leads to unavailability of sufficient physiological stress conditions, very much crucial for satisfactory induction of flowering in 'Alphonso' under tropical conditions, thereby impacting flowering adversely.

Normally rainfall ceases by September end followed by onset of winter from November that continues up to February in the Konkan region. However, due to delayed and extended rains, this normal weather cycle is found disturbed and the much needed physiological stress preceding fruit bud differentiation are lacking and as a consequence, uncontrolled vegetative flushes have been occurring. Agro-climate, further impacted by extended cold periods ( $>122$ days of $<17^{0} \mathrm{C}$ in 2011-12), 'Alphonso' manifested three reproductive flushes in the fruiting season despite favorable weather conditions prevailing subsequently. Similarly, continuance of severe cold for extra long periods (62 to 74 days) also prevailed during 2009 and 2010 fruiting seasons that resulted in altered phenophases dynamics in 'Alphonso'. As a result the inflorescences emerging during this period were abnormal like extra long flowering panicles (42 to $45 \mathrm{~cm}$ ); instead of normal (29 to $32 \mathrm{~cm}$ ), mixed panicles and changed sex ratio. During 2010-2011, severe cold period $\left(<17^{\circ} \mathrm{C}\right)$ continued for 72 days (instead of 4 to 5 spells of 15 days period) which led to development of extra long inflorescences with altered sex ratio (4 to $5 \%$ hermaphrodite flowers) characterized by preponderance of male flowers (96\%) adversely impacting fruit set; the reduced number and activity of pollinators further compounding the problem . Majority of the inflorescences of this period failed to set fruits due to inadequate pollination and hence subsequently dried up.

Intermittent flowering phenomenon in the peninsular region in the recent years since 2008 is posing serious problems. During January 2013, $\mathrm{T}_{\min }$ of the region, ranged between 13 to $16^{\circ} \mathrm{C}$, but on majority of the days it was between 14 to $15^{\circ} \mathrm{C}$. In the first fortnight of January $2013, \mathrm{~T}_{\min }$ recorded was between 11 to $18^{\circ} \mathrm{C}$ and 10 to $16^{\circ} \mathrm{C}$. Hence, during 2013 fruiting season, the flowering flushes occurred more than twice attributable 
to this variation. During February 2013 , the $\mathrm{T}_{\max }$ was $28.7^{\circ} \mathrm{C}$ and the $\mathrm{T}_{\min }$ was $17.4^{0} \mathrm{C}$ and the RH was $73 \%$. The data recorded for two fortnights revealed very little difference between $\mathrm{T}_{\max }$ and $\mathrm{T}_{\min }$. However, large variations in the $\mathrm{T}_{\min }$ were seen during February. On some days the $\mathrm{T}_{\min }$ was $21^{0} \mathrm{C}$ and in some days after a gap of 6 to 7 days, the same declined to $14^{\circ} \mathrm{C}$. This probably triggered a wave of second flush of flowering in 2013 fruiting season (Personal communication, 2013). However, during February 2012, the minimum temperature always had hovered between 13 to $15^{\circ} \mathrm{C}$ without much change. Similar observations of 'recurrent flowering' phenomenon and occurrence of fruits of different developmental stages on the same tree have also been reported from Gujarat and Odisha (Personal communication, 2013).

A similar environmental cue prevailed in Lucknow region wherein the cold periods $\left(<17^{0} \mathrm{C}\right)$ were recorded from $15^{\text {th }}$ October onwards in 2011-12 and 2012-13 (Figure 10). , The cold periods were found extended for at least a fortnight more in 201213 (around 169 days) as compared to 2011-12 (around 155 days). These extended cold periods impacted flowering phenology adversely; vegetative flushes emerging concomitantly with flowering, and altered pests and diseases dynamics in 'Dashehari' (thrips ; anthracnose) besides low number and activity of pollinators . Occurrence of frost $\left(-0.2^{0} \mathrm{C}\right.$ to $-1.2^{0} \mathrm{C}$ on $9^{\text {th }}$ and $10^{\text {th }}$ January, 2013) was the other notable feature that killed the shoot apices including shoot portion of about 5-6 inches (Photograph 1).

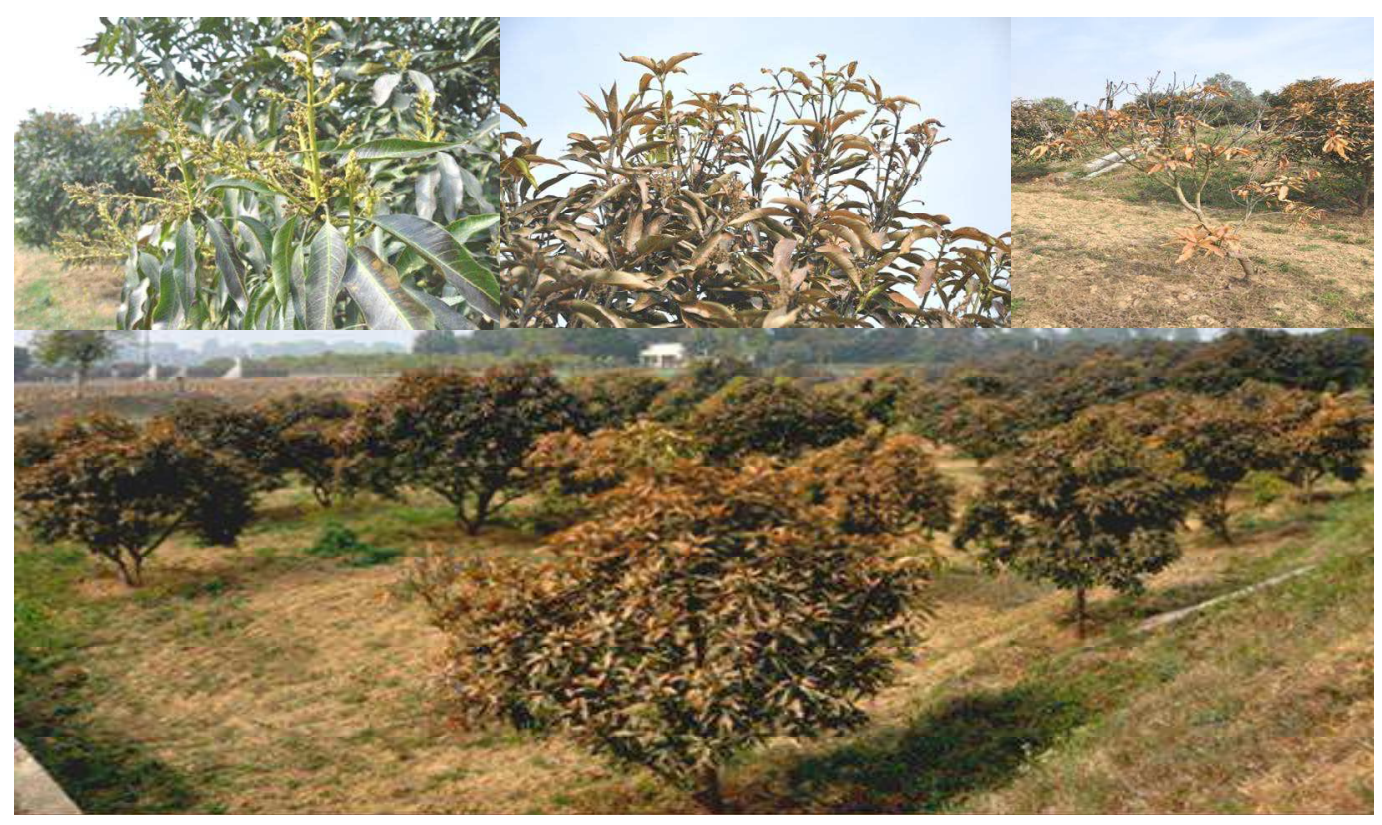

Photgraph.1. Frost damages to shoot apices, inflorescences and mango young plants in January 2013

Early flowering in some mango cultivars during December was found subjected to frost injuries $\left(-0.2^{0} \mathrm{C}\right.$ to $-1.2^{0} \mathrm{C}$ on $9^{\text {th }}$ and $10^{\text {th }}$ January, 2013) resulting in drying up of 
inflorescences giving charred appearance. Extended cold periods of 2012-13 fruiting season as indicated (Figure.10), have besides adversely impacting the flowering phenology across varieties including delayed flowering (late February-early March,2013), may possibly also render fruit growth and development stages vulnerable to eventually increased hot and dry environmental cues, with adverse impacts on later stages of fruit development especially, maturity (during June to July). All these factors cumulatively may reduce the quantity and quality of fruit harvests in 2012-13 fruiting season.

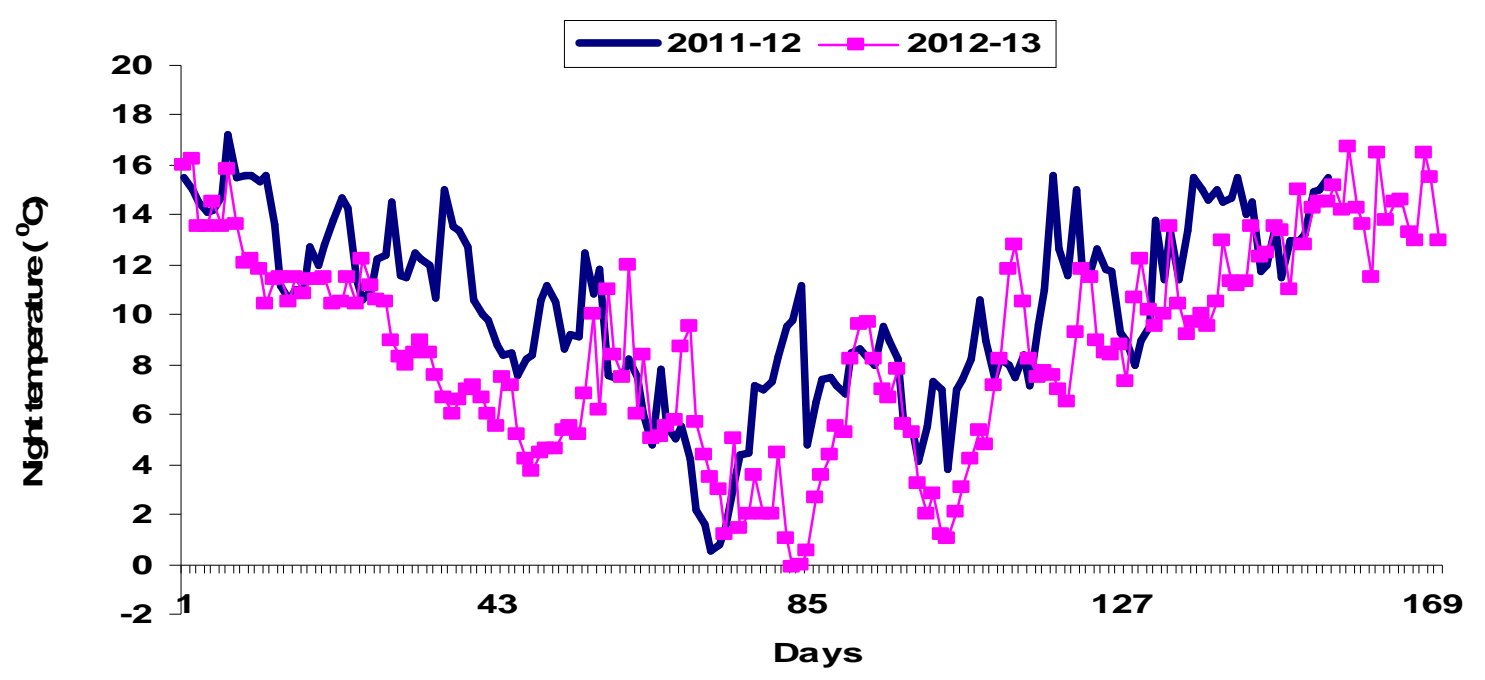

Figure 10. Extended cold periods $\left(<17^{0} \mathrm{C}\right)$ from $15^{\text {th }}$ October onwards during 201112 and 2012-13

\subsubsection{Nubbin fruit formation}

'Dashehari' cultivar, being highly sensitive to temperature fluxes in respect of key reproductive phenophases viz., flowering and fruit set, also gets highly impacted by the abnormal weather conditions especially, the spatio-temporal relationships between $\mathrm{T}_{\max }$ and $\mathrm{T}_{\min }$. The clustering (nubbin) of fruit lets phenomenon may be due to prevalence of high fluctuations in temperatures during February and March especially, the $\mathrm{T}_{\min }$ of cold winters which coincided with the period of flowering and fruit development during 2013 fruiting season probably impacted by hormonal interpolations ; this type of weather extremism despite good intensity of flowering and set, often ends up in clustering of fruit lets at the distal end of the inflorescence where, higher percentage of perfect flowers normally occurred in the panicle configuration. Such fruits invariably with aborted embryos (see the inset picture) prematurely drop off and are not carried to maturity, a direct loss to total crop outputs. 


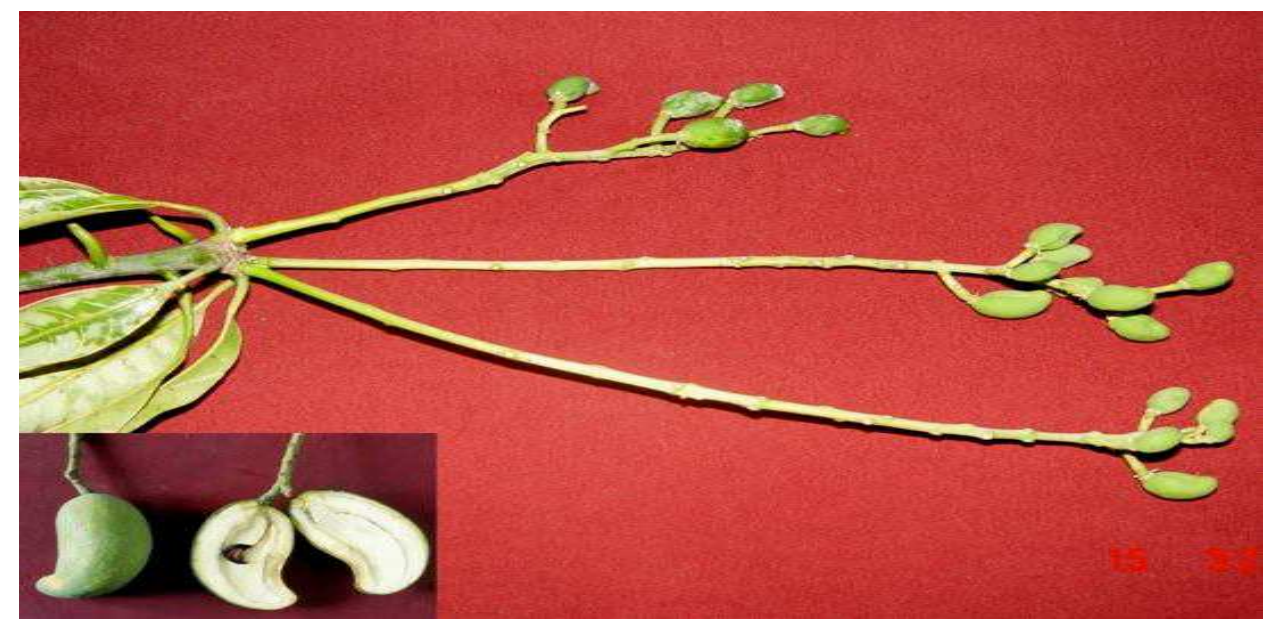

Photograph.2. Clustering of fruits in mango (nubbin fruits formation);

Inset: LS of fruits showing embryo abortion.

Hormonal relationships also explained that, the normal fruits contained higher concentrations of gibberellins and cytokinins and lower concentrations of auxins and abscissic acid as compared to the nubbin fruits. These findings perhaps explained the reasons of occurrence nubbin fruits that have a slower growth rate than the seeded one and small in size, majority of these fruits dropped and failed to reach full size (Shaban and Ibrahim, 2009). Variety differences, effects of cold winter temperatures in this regard though have been implicated; exact reasons for this phenomenon however are not clearly understood (Campbell and Campbell, 1991).

'Jelly seed' formation, a physiological disorder widely occurring in 'Dashehari' affects the market prospects, appears to be related to reduced internal calcium allocation to fruits under the influence of high temperature holds ground in light of the observations of Batten et al., (1988) as its incidence increased in late harvested fruits exposed to high temperatures $\left(\mathrm{T}_{\max }>40^{\circ} \mathrm{C}\right)$. This view is also substantiated by the results of Singh et al., (2006) that highlighted the factors of late harvesting after a spell of rains, and association of fruit transpiration with internal break down in'Dashehari' . Singh (2007) found spraying of dehydrated Calcium chloride $(2.0 \%)$ in combination with potassium sulphate (1.0\%) along with soil application of borax (150-250 g per tree) in October-November, a month before harvesting of fruits controlled this disorder.

\section{CONCLUSIONS}

The flowering in mango whether in regular or irregular bearing varieties is the result of hormonal interpolations within the plant system under the strong influence of environmental factors especially the $\mathrm{T}_{\min }$ though other components could also impact adversely the mango phenophases, about which sufficient quantified data are not 
available. This environmental variable has been studied widely in mango by many researchers. Other environmental cues viz., light, water, sunshine hours, wind, salinity though exert considerable influence on productivity as has been reported in few cases have not been systematically investigated across agro-ecologies and varieties, hence delineation of their specified roles remains severely constrained. Experiences have shown that the above factors many times, either individually or synergistically influence productivity through their impacts on phenophases responses within a given fruiting season, their effects getting perpetuated in the following years. Studies to intervene and manipulate phenophases / tree physiology aberrations both in the country as well as in other mango producing countries of the world, by the use of 'Paclobutrazol' which is anti-gibberellins, through its physiological action promotes flower induction at the expense of vegetative growth. Its uncontrolled use however, year after year without ensuring adequate foundation growth of active shoot mass per tree by appropriate crop husbandry practices, besides disturbing the phenological phases which, otherwise normally under intimate balance also has residue problems with attendant environmental concerns. This, prominently flags for focused research on the role of root dynamics in regulation of flowering in mango as 'root signals' arising out down /up regulating of certain genes appear critical. The dynamism of temperature fluxes, unpredictable though , as has been occurring in some parts of the country especially, in the regions of Karnataka, Maharashtra, Gujarat, Odisha, West Bengal in the recent years, appears to be adversely impacting productivity through induction of 'recurrent flowering' over several short spells within the same fruiting season. This phenological aberration could have cascading effects on tree physiology in a perennial tree crop like mango, the details of which however needs to be investigated critically. Meanwhile, it is of interest to note here that some of the exotic colored varieties viz., Tommy Atkins and Kent etc., showing resilience to weather dynamics by such features as high percentage of hermaphrodite flowers, fruit set per panicle, fruit retention to final harvest, yield potential even under adverse weather dynamics as is being observed under the Konkan conditions, should prompt the researchers to delve into the association of genes responsible for color trait with the climate resilience trait(s). This empirical appraisal once again prominently flags the research gap in the valuation of the diverse genetic resources under different mango producing ecologies for their responses to varied changes of agro-climatic conditions so that appropriate gene products could be profiled in order to exploit biotechnological tools to address the challenges of developing climate resilient varieties. The economy and livelihoods of the growers since in many traditional regions are intricately linked to the mango productivity, undertaking macro and micro climate analysis will ultimately lead to the development of site-specific decision support systems for empowering local mango grower communities for adopting improved crop husbandry practices to mitigate the adverse effects of changing weather extremisms.

\section{REFERENCES}

Adak , T., Kumar K., Shukla R.P. and Ravishankar, H. 2012. Weather based agroadvisory inputs for decision support mechanism for improving mango production in 
Lucknow region of Uttar Pradesh. In: Proceedings of the National Seminar on "New Frontiers and Future Challenges in Horticultural Crops" at PAU, Ludhiana India, held during 15-17 ${ }^{\text {th }}$ March, 2012. pp 56.

Agarwal, P.K. 2009 . Global climate change and Indian agricultural case studies from ICAR network project, ICAR, New Delhi, 2009.

Abdul Vahab Abdul Haris , Sandeep Biswas, Vandana Chhabra , Rajamanickam Elanchezhian and Bhagwati Prasad Bhatt, 2013. Impact of climate change on wheat and winter maize over a sub-humid climatic environment. Current Science, (104) No.2 . 206214 .

Batten, D.J., Firth , D., and A. Miller.1988. Sensation mango research. Subtrop . Fruit Grower, 4,13.

Bruce Schaffer , Anthony, W., and J. H. Crane . 1994. Mango . In: Handbook of Environmental Physiology of Fruit Crops (Eds.) Bruce Schaffer and P.C. Anderson. CRC Press Inc. Boca Raton, Florida, 33431.pp.165-196.

Campbell, R.J. and C.W. Campbell .1991. The Parvin mango. Proc.Fla. State Hort.Soc., 104: 47-48.

Chacko, E.K. 1991. Mango flowering-still an enigma . Acta Hort ., 291,12.

IPCC, Summary for policy makers. In: Climate change 2007.The Physical Science Basis, Contribution of Working Group (WG) to the Fourth Assessment Report of the Intergovernmental Panel on Climate Change (eds. Solomon, S. et al.,), Cambridge University Press, Cambridge, UK,2007.

Issarakraisila, M., Considine , J.A., and D.W. Turner. 1992. Seasonal effects on floral biology and fruit set of mangoes in a warm temperate region of Western Australia. Acta Hort ., 321,626.

Issarakraisila , M., and J.A.Considine .1994. Effects of temperature on microsporogenesis and pollen viability in mango cv. Kensington. Ann. Bot., 73, 231.

Kachru , R.B., Singh, R.N., and Chacko, E.K. 1971. Inhibition of flowering in mango (Mangifera indica L.) by gibberellic acid. Hort Science, 2, 140.

Pongsomboon, W. 1991. Effects of temperature and water stress on tree growth, flowering, fruit growth and retention of mango (Mangifera indica L.) , Ph.D Thesis , Kasetstart University, Bangkok, Thailand

Ravishankar, H. 1987. Studies on the physiological and biochemical aspects into the causes and control of alternate bearing in mango (Mangifera indica L.) . Ph.D Thesis, University of Agricultural Sciences, Dharwad, p.310. 
Ravishankar, H., Adak, T., Kumar K. and R.P. Shukla . 2011. Some aspects of weather dynamics influencing production and sustainability of mango (Mangifera indica L.) in Malihabad belt of Uttar Pradesh. In: International Conference on Issues for Climate Change, Land Use Diversification and Biotechnological Tools for Livelihood Security, October 8-10, 2011, SVPUA\&T, Meerut, U.P., India, p 208-209.

Shaban, A. E. A. and A.S.A. Ibrahim, 2009. Comparative study on normal and nubbin fruits of some mango cultivars. Australian Journal of Basic and Applied Sciences, 3 (3): 2166

Singh, R.N., Majumdar, P.K., and D.K. Sharma . 1965. Studies on the bearing behavior of some south Indian varieties of mango (Mangifera indica L.) under North Indian conditions. Trop Agri., 42,171.

Singh, V.K., Singh, D.K. and S.M. Pathak . 2006. Relationship of leaf and fruit transpiration rates to the incidence of softening of tissue in mango (Mangifera indica L.) cultivars .American. J. Pl. Physiol., 1 (1) : 28-33

Singh, V.K. 2007. Jelly seed in mango and its management. ICAR News, A Science and Technology Newsletter, ICAR, New Delhi, April-June, 2007, pp.13-14

Singh, V.K. and S. Rajan. 2009. Changes in photosynthetic rate, specific leaf weight and sugar contents in mango (Mangifera indica L.). The Open Horticulture Journal, 2: 3437.

Singh, V.K., H. Ravishankar and Sridhar Gutam . 2012. Physiological attributes in mango (Mangifera indica L.) impacted by different $\mathrm{CO}_{2}$ and temperature fluxes under Lucknow conditions. In: National Dialogue on Climate Resilient Horticulture, 28-29 January, 2012, Indian Institute of Horticultural Research, Hessaraghatta Lake Post, Bangalore, p- 147-153.

Whiley, A.W., Rasmussen, T.S., Saranah, J.B., and B. N. Wolstenholme. 1989. Effect of temperature on growth, dry matter production and starch accumulation in ten mango (Mangifera indica L.) cultivars. J. Hort. Sci., 64, 753. 